\title{
NILAI PENDIDIKAN KELUARGA \\ DALAM SERAT LAYANG SRI JUWITA KARYA MAS SASRA SUDIRJA
}

Yuli Widiyono

Universitas Muhammadiyah Purworejo

\begin{abstract}
Abstrak
Makalah ini membahas tentang ajaran berumah tangga dalam serat Layang Sri Juwita karya Mas Sasra Sudirja. Serat tersebut berisi tentang perjalanan hidup kaum perempuan dan tugas dan kewajiban suami.

Layang Sri Juwita karya Mas Sasra Sudirja yang merupakan naskah yang terbagi menjadi tujuh bab yaitu; mencari penghasilan, anak orang kecil, anak perempuan, anak perempuan yang sudah berumah tangga, pitutur yang baik, menjaga rumah tangga, dan peranan perempuan. Dalam naskah tersebut membahas tentang perjalanan kaum perempuan dan kewajiban suami dalam sosial masyarakat. Naskah tersebut digambarkan bagaimana kehidupan masyarakat Jawa ketika mereka harus mencari penghasilan untuk memenuhi kebutuhan hidup, bagaimana kehidupan rumah tangga antara suami dan istri, peran orang tua yang ikut serta dalam penentuan jalan hidup seorang anak. Semua hal yang ada dalam naskah memberikan pelajaran bagaimana cara mendidik anak agar menjadi seseorang yang bisa bertanggung jawab pada dirinya dan orang lain, serta menyadarkan bagaimana seorang suami dan istri seharusnya hidup dalam berumah tangga. Dengan mengilhami isi ajaran dalam serat Layang Sri Juwita diharapkan mampu memberikan informasi serta peranan dalam meningkatkan budi pekerti dan nilai pendidikan keluarga, sosial masyarakat, menuju peradaban bangsa yang bermartabat dan memiliki karakter yang kuat dengan menghargai nilai-nilai budaya kearifan lokal.
\end{abstract}

Kata kunci: nilai, pendidikan, keluarga, Layang Sri Juwita

\section{PENDAHULUAN}

Perkembangan peradaban manusia mengalami perubahan yang sangat cepat. Perkembangan tersebut ditandai dengan adanya perubahan budaya yang ada di masyarakat. Perubahan kebudayaan tersebut hampir meliputi semua unsur budaya yang ada di masyarakat. Koentjaraningrat (1985) menyebutkan ada tujuh unsur-unsur kebudayaan yang ada di masyarakat. Ketujuh unsur kebudayaan tersebut adalah sistem religi, sistem organisasi masyarakat, sistem pengetahuan, sistem mata pencaharian hidup dan sistem-sistem ekonomi, sistem teknologi dan peralatan, bahasa, dan kesenian. Ketujuh unsur tersebut telah mengalami perubahan yang sangat cepat, misalnya Sistem mata pencaharian masyarakat Jawa yang berkembang mengikuti perubahan jaman yang semakin maju. Demikian juga perkembangan teknologi yang semakin canggih membuat perkembangan ilmu pengetahuanpun berkembang mengikuti arus jaman. 
Sistem teknologi yang berkembang sekarang tentunya berbeda dengan sistem teknologi sebelumnya. Hasil peninggalan teknologi pada jaman-jaman terdahulu misalnya berupa karya sastra. Media yang digunakan dalam penyampaian ide, gagasan, ataupun pengalaman penulis yang disajikan juga berbeda. Hasil karya sastra tersebut berupa naskah. Media aksara yang digunakan pada naskah tersebut tentunya memiliki eksistensi yang berbeda. Naskah sebagai hasil karya yang sekarang tersimpan pada beberapa perpustakaan, memiliki nilai yang sangat tinggi, baik nilai sejarah, edukatif, maupun nilai kultural yang sangat beragam.

Karya Sastra merupakan hasil ciptaan bahasa yang indah atau hasil kehidupan jiwa yang terjelma dalam tulisan atau bahasa tulis yang menggambarkan atau mencerminkan peristiwa kehidupan masyarakat atau anggota masyarakat. Karya sastra adalah karya imajinatif pengarang yang menggambarkan kehidupan masyarakat pada waktu karya sastra itu diciptakan Kehadiran sastra diterima sebagai salah satu realitas soaial budaya. Karya sastra tidak saja dinilai sebagai sebuah karya seni yang memiliki budi, imajinasi, dan emosi, tetapi telah diangap sebagai suatu karya kreatif yang dimanfaatkan sebagai konsumsi emosi dan intelektual.

Naskah merupakan bentuk manifestasi kehidupan bangsa dan akan menjadi peninggalan kebudayaan yang sangat tinggi nilainya, khususnya kebudayaan Jawa yang adiluhung. Kajian terhadap naskah akan memberikan informasi tentang kehidupan yang dapat diajarkan untuk generasi berikutnya. Informasi tentang hasil budaya bangsa khususnya Indonesia dapat terungkap melalui pembacaan maupun penelitian yang terdapat dalam bentuk naskah. Informasi-informasi yang diperoleh melalui kajian filologi ini, tentunya akan memberikan nilai yang bisa diterapkan dalam kehidupan, sebatas nilai tersebut masih relevan dengan kehidupan sekarang. Karya sastra berupa naskah Jawa banyak memuat ajaranajaran serta nilai-nilai adiluhung yang bersifat mendidik. Hal tersebut senada dengan Edi Sedyawati (2001:138) yang menyatakan bahwa setiap karya sastra Jawa mengandung banyak teladan, kegunaan dari budi pekerti manusia, dalam kriteria ini terutama bagi orang muda dan anak-anak.

Serat Layang Sri Juwita merupakan naskah yang media penyampaiannya menggunakan aksara Jawa. Serat tersebut membahas masalah kehidupan masyarakat dalam menjalani kehidupan. Dalam naskah tersebut membahas tentang perjalanan kaum perempuan dan kewajiban suami dalam sosial masyarakat. Naskah tersebut digambarkan bagaimana kehidupan masyarakat Jawa ketika mereka harus mencari penghasilan untuk memenuhi kebutuhan hidup, bagaimana kehidupan rumah tangga antara suami dan istri, peran orang tua yang ikut serta dalam penentuan jalan hidup seorang anak. Semua hal yang ada dalam naskah memberikan pelajaran bagaimana cara mendidik anak agar menjadi seseorang yang bisa bertanggung jawab pada dirinya dan orang lain, serta menyadarkan bagaimana seorang suami dan istri seharusnya hidup dalam berumah tangga.

Pendidikan berumah tangga sangat berperan dalam membentuk watak, karakter maupun budi pekerti anak. Hal ini berhubungan dengan masalah kesiapan dalam menghadapi tantangan maupun ancanam yang datang secara cepat. 
Perkembangan teknologi sekarang ini, ternyata tidak hanya memberikan dampak positif namun juga memberikan dampak negatif. Masalah degradasi moral sumber daya manusia Indonesia perlu segera mendapat penanganan khusus. Hal tersebut dapat diketahui melalui informasi media massa baik eletronik mapun cetak. Salah satu upaya penanganan khusus tersebut melalui pendidikan budi bekerti dalam keluarga. Keluarga merupakan lembaga pertama dalam kehidupan orang tua, anak, tempat belajar dan menyatakan diri sebagai makhluk sosial. Segala sesuatu yang diperbuat oleh orang tua berpengaruh pada seluruh keluarga. Keluarga memberikan dasar-dasar pembentukan tingkah laku, watak, moral, budi pekerti dan pendidikan kepada anak. Pengalaman interaksi di dalam keluarga akan menentukan pula pola tingkah laku anak terhadap orang lain dalam masyarakat. Melalui kajian ini, berbagai informasi yang diperoleh diharapkan menjadi sumber informasi atau pembelajaran yang dapat membina pendidikan karakter dan nilai budi pekerti.

\section{Nilai Pendidikan Keluarga}

Pengertian nilai pendidikan moral sebelum mengungkap pengertian tersebut, akan dibahas pengertiannya masing-masing. Hal tesebut untuk memudahkan rumusan tentang pengertian nilai pendidikan moral.

Nilai adalah sifat-sifat atau hal-hal yang penting dan berguna bagi kemanusiaan. Sementara itu, Mardiatmaja (1986:55) menyatakan bahwa nilai merujuk pada sikap orang terhadap sesuatu hal yang baik. Nilai-nilai dapat saling berkaitan membentuk suatu sistem antara satu dengan yang lain, kohern dan mempengaruhi segi kehidupan manusia. Hal senada juga diungkapkan The Liang Gie (1982: 159) yang berpendapat bahwa nilai adalah sesuatu yang menimbulkan minat (interest), sesuatu yang lebih disukai (preference), kepuasan (satisfaction), keinginan (desire), kenikmatan (enjoyment). Nilai selalu menjadi ukuran dalam menentukan kebenaran dan keadilan, sehingga tidak akan pernah lepas dari sumber asalnya yaitu berupa nilai ajaran agama, logika, dan norma-norma yang berlaku dalam masyarakat. Nilai merupakan suatu konsep, yaitu pembentukan mental yang dirumuskan dari tingkah laku manusia sehingga menjadi sejumlah anggapan yang hakiki, baik dan perlu dihargai sebagaimana mestinya.

Nilai mempunyai fungsi untuk membentuk cara berfikir dan tingkah laku secara ideal dalam masyarakat. Sejak kecil seseorang dididik oleh orang tuanya, kerabat, ataupun masyarakat tentang baik-buruk, benar-salah, bagus-jelek, serta sopan dan tidak sopan secara terus menerus sehingga membentuk cara pandang dan sikap hidup ideal dalam masyarakat. Sebagai contoh, orang tua yang sudah mengasuh dan mengasihi anak-anaknya tentu saja sikap anak terhadap orang tuanya hendaknya menghargai, dan hal itu tercermin dalam sikap sopan santun, baik dalam bicara maupun dalam bersikap kepada orang lain.

Pengertian nilai adalah harga tentang sesuatu mempunyai nilai karena dia mempunyai harga atau sesuatu itu mempunyai harga karena ia mempunyai nilai. Nilai bersifat ide atau abstrak (tidak nyata). Nilai bukanlah suatu fakta yang dapat ditangkap oleh indra. Tingkah laku perbuatan manusia atau sesuatu yang mempunyai nilai itulah yang dapat ditangkap oleh indra karena ia bukan fakta yang nyata (Akhmad Sudrajat, 2008: 8). Nilai pendidikan dapat diperoleh 
pembaca setelah membaca karya sastra. Dengan membaca, memahami, dan merenungkannya pembaca akan memperoleh pengetahuan dan pendidikan. Lebih lanjut Atar Semi (1994:20) mengungkapkan bahwa nilai dalam karya sastra diharapkan dapat memberi solusi atau sebagian masalah dalam kehidupan masyarakat. Tujuan pendidikan memuat gambaran tentang nilai-nilai yang baik, luhur, pantas, benar, dan indah untuk kehidupan. Pendidikan memiliki dua fungsi yaitu memberikan arah kepada segenap kegiatan pendidikan dan merupakan sesuatu yang ingin dicapai oleh segenap kegiatan pendidikan (Hartoto, 2009: 8).

Sementara itu Sastrowardoyo (dalam Nani Tuloli, 1999: 232) menjelaskan bahwa dalam masyarakat modern kesastraan dapat berkembang dengan subur dan nilai-nilainya dapat dirasakan manfaatnya oleh umum. Kesustraan sendiri mengandung potensi-potensi kearah keluasan kemanusiaan dan semangat hidup yang mengandung ekpresi pribadi meliputi tingkat pengalaman biologi, sosial, intelektual, dan religious. Nilai-nilai tersebut dibutuhkan dalam masyarakat yang dapat dituangkan dalam karya sastra.

Batasan tentang pendidikan yang dibuat oleh para ahli beraneka ragam, dan kandungannya berbeda yang satu dari yang lain. Perbedaan tersebut mungkin karena orientasinya, konsep dasar yang digunakan, aspek yang menjadi tekanan atau karena falsafah yang melandasinya.

1. Pendidikan sebagai proses transformasi budaya

Sebagai proses transformasi budaya, pendidikan diartikan sebagai kegiatan pewarisan budaya dari satu generasi ke generasi yang lain. Nilai-nilai budaya tersebut mengalami proses transformasi dari generasi tua ke generasi muda. Ada tiga bentuk transformasi yaitu nilai-nilai yang masih cocok diteruskan misalnya nilai-nilai kejujuran, rasa tanggung jawab, dan lain-lain.

2. Pendidikan sebagai proses pembentukan pribadi

Sebagai proses pembentukan pribadi, pendidikan diartikan sebagi suatu kegiatan yang sistematis dan sistemik terarah kepada terbentuknya kepribadian peserta didik. Proses pembentukan pribadi melalui 2 sasaran yaitu pembentukan pribadi bagi mereka yang belum dewasa oleh mereka yang sudah dewasa dan bagi mereka yang sudah dewasa atas usaha sendiri.

3. Pendidikan sebagai proses penyiapan warganegara

Pendidikan sebagai penyiapan warganegara diartikan sebagai suatu kegiatan yang terencana untuk membekali peserta didik agar menjadi warga negara yang baik.

4. Pendidikan sebagai penyiapan tenaga kerja

Pendidikan sebagai penyimpana tenaga kerja diartikan sebagai kegiatan membimbing peserta didik sehingga memiliki bekal dasar utuk bekerja. Pembekalan dasar berupa pembentukan sikap, pengetahuan, dan keterampilan kerja pada calon luaran. Ini menjadi misi penting dari pendidikan karena bekerja menjadi kebutuhan pokok dalam kehidupan manusia.

Wuradji (1988: 9) menyatakan bahwa pendidikan sebagai lembaga konservatif mempunyai fungsi-fungsi sebagai berikut: (1) Fungsi sosialisasi, (2) 
Fungsi kontrol sosial, (3) Fungsi pelestarian budaya Masyarakat, (4) Fungsi latihan dan pengembangan tenaga kerja, (5) Fungsi seleksi dan alokasi, (6) Fungsi pendidikan dan perubahan sosial, (7) Fungsi reproduksi budaya, (8) Fungsi difusi kultural, (9) Fungsi peningkatan sosial, dan (10) Fungsi modifikasi sosial.

Pendidikan diartikan sebagai kegiatan yang sistematis dan sistemik terarah kepada terbentuknya kepribadian peserta didik. Pendidikan sebagai proses penyiapan warga negara. Pendidikan diartikan sebagai suatu kegiatan yang terencana untuk membekali peserta didik agar menjadi warga negara yang baik. Pendidikan sebagai penyiapan tenaga kerja. Pendidikan diartikan sebagai kegiatan membimbing peserta didik sehingga memiliki bekal dasar untuk bekerja.

Keluarga (bahasa) berasal dari dua struktur kata, yakni kata kula dan warga. Kula berarti abdi atau hamba. Warga berarti anggota. (Hidayat, 2008: 31). Keluarga adalah sanak saudara yang bertalian darah karena faktor keturunan yang dihasilkan atas dasar perkawinan. (Kamus Umum Bahasa Indonesia, 1980: 471). Keluarga merupakan lingkungan pertama dan utama bagi anak, oleh karena itu orang tua (keluarga) mempunyai peranan yang dominan dalam pengembangan kesadaran beragama anak. (Yusuf, 2008: 41). Keluarga adalah unit terkecil dalam suatu masyarakat yang terdiri atas ayah, ibu, anak-anak dan kerabat lainnya.

Menurut Amini (107: 2006) keluarga adalah orang-orang yang secara terus menerus atau sering tinggal bersama si anak, seperti ayah, ibu, kakek, nenek, saudara laki-laki dan saudara perempuan dan bahkan pembantu rumah tangga, diantara mereka disebabkan mempunyai tanggung jawab menjaga dan memelihara si anak dan yang menyebabkan si anak terlahir ke dunia, mempunyai peranan yang sangat penting dan kewajiban yang lebih besar bagi pendidikan si anak. Menjadi ayah dan ibu tidak hanya cukup dengan melahirkan anak, kedua orang tua dikatakan memiliki kelayakan menjadi ayah dan ibu manakala mereka bersungguh-sungguh dalam mendidik anak mereka.

Dari penjelasan di atas dapat disimpulkan bahwa yang dimaksud dengan keluarga adalah kesatuan unsur terkecil yang terdiri dari bapak, ibu dan beberapa anak. Masing-masing unsur tersebut mempunyai peranan penting dalam membina dan menegakkan keluarga, sehingga bila salah satu unsur tersebut hilang maka keluarga tersebut akan guncang atau kurang seimbang. Keluarga mempunyai peranan penting dalam pendidikan, baik dalam lingkungan masyarakat Islam maupun non-Islam. Karena keluarga merupakan tempat pertumbuhan anak yang pertama di mana dia mendapatkan pengaruh dari anggota-anggotanya pada masa yang amat penting dan paling kritis dalam pendidikan anak, yaitu tahun-tahun pertama dalam kehidupannya (usia prasekolah), sebab pada masa tersebut apa yang ditanamkan pada diri anak akan sangat membekas, sehingga tak mudah hilang atau berubah sesudahnya. Dari sini, keluarga mempunyai peranan besar dalam pembangunan masyarakat.

\section{HASIL PENELITIAN DAN PEMBAHASAN}

\section{Nilai Pendidikan Keluarga Dalam Serat Layang Sri Juwita}

Nilai pendidikan keluarga dalam naskah serat Layang Sri Juwita, secara singkat penulis sajikan sebagai berikut: 
1) Suami bisa menjadi tauladan

Dalam menjalani kehidupan keluarga atau berumah tangga, tujuan yang hendak dicapai adalah mewujudkan keluarga yang sejagtera, baik lahir maupun batin. Dalam bidang keagamaan khusunya Islam, dambaan setiap keluarga adalah bisa menjadi keluarga sakinah, mawadah, warahmah. Kriteria tersebut tentunya butuh konsistensi kedua pasangan. Salah satu peran keluarga yang dibutuhkan untuk menjadi keluarga tersebut adalah sosok suami yang bisa menjadi tauladan untuk isitri dan anak-anaknya. berikut kutipan dari serat tersebut:

"Mungguh sejatine wong omah-omah lan laki rabi iku kang kudu kuwat lan dadi pangareping ya wong lanang. Tegese kang murba mise sabojo sarayate kabeh iya wong lanang iku, dadi samangsa kang kajibah mangkono wis ora mraduli, wewangkone iya dadi bubrah. Wekasan rusak uripe."

(LSJ: 38)

'Padahal sejatinya dalam berumah tangga yang harus kuat dan menjadi contoh adalah laki-laki. Artinya yang bertanggung jawab atas istri dan anaknya semua adalah laki-laki, jadi ketika yang mempunyai tanggung jawab seperti itu sudah tidak peduli, yang didapat jadi kacau. Akhirnya rusak hidupnya.'

Kutipan di atas menjelaskan bahwa dalam kehidupan rumah tangga, lakilaki harus mempunyai kekuatan dan harus bisa menjadi contoh bagi keluarganya. Sosok seorang laki-laki digambarkan sebagai sosok yang bisa meindungi dan mengayomi dalam keluarga. Dalam serat tersebut dijelaskan bahwa yang bertanggung jawab mencukupi kebutuhan anak dan istri adalah suami. Dalam sebuah keluarga apabila seorang suami tidak lagi peduli akan tugasnya itu, maka bisa berdampak pada kegagalan yang berujung pada kehancuran rumah tangga. Dari kutipan tersebut bisa diambil pesan bahwa, sosok seorang suami adalah menjadi suami yang kuat, bertanggung jawab sehingga mampu membina keluarga menjadi keluarga yang baik.

2) Suami berkewajiban mencari nafkah

Syarat seorang laki-laki untuk bisa berkeluarga adalah sudah mempunyai penghasilan yang dianggap cukup. berikut kutipan dalam serat Layang Sri Juwita:

"Wong lanang kudu ngupa jiwa, apa olehe dipasrahake marang bojone. Sing wadon kang nindakake lan rumeksa kabutuhan ing sadina-dina, asarana nganggo dhuwit pekane sing lanang mau. Pirang bara wong wadon bisa reka-reka mitulungi kabutuhan sawatara amurih enthenging guru laki. Orane janji wis bisa ambage apa kang ditompa iku wis aran cukup, aliya iku sarehning wong lanang wis abot enggone luru pangan. Dadi kang mranata resik lan prayogane sajroning omah iya wong wadon $i k u$, apa kang perlu kanggo, lan apa kakurangane kabeh wong wadon mesthi meruhi." (LSJ: 38-39)

'Laki-laki harus bekerja, apa yang didapat diberikan kepada istrinya. Yang perempuan melaksanakan dan menjaga kebutuhan sehari-hari, dengan uang yang dihasilkan oleh suami tadi. Nantinya perempuan bisa mereka-reka 
membantu kebutuhan sementara untuk meringankan laki-laki. Tidak janji bisa membagi apa yang diterima itu sudah bisa dikatakan cukup, atau itu karena laki-laki berat dalam mencari makan. Jadi yang menata membersihkan dan baiknya dalam rumah adalah perempuan, apa yang diperlukan, dan apa kekurangannya semua perempuan pasti mengetahui.'

Dari kutipan tersebut tampak bahwa laki-laki harus bekerja. Suami berkewajiban mencari nafkah untuk mencukupi kebutuhan keluarga. Nafkah yang diperoleh, tentunya naskah yang diperoleh dengan cara yang baik. Hasil yang didapatkan suami nantinya diberikan kepada istri. Dari uang pemberian suami, istri harus bisa mengelola uang tersebut untuk mencukupi kebutuhan rumah tangganya. Kemudian istri bertugas mengatur isi rumah serta membersihkan rumah.

3) Istri bisa mengelola keuangan rumah tangga

Dalam naskah tersebut dijelaskan bahwa semua jerih paying yang diperoleh oleh suami wajib diserahkan kepada istri. Tugas dari seorang istri adalah harus bisa menjaga dan mengatur keuangan dalam keluarga. kutipan tersebut sama halnya kutipan sebelumnya, yaitu:

"Wong lanang kudu ngupa jiwa, apa olehe dipasrahake marang bojone. Sing wadon kang nindakake lan rumeksa kabutuhan ing sadina-dina, asarana nganggo dhuwit pekane sing lanang mau. Pirang bara wong wadon bisa reka-reka mitulungi kabutuhan sawatara amurih enthenging guru laki. Orane janji wis bisa ambage apa kang ditompa iku wis aran cukup, aliya iku sarehning wong lanang wis abot enggone luru pangan. Dadi kang mranata resik lan prayogane sajroning omah iya wong wadon $i k u$, apa kang perlu kanggo, lan apa kakurangane kabeh wong wadon mesthi meruhi."

(LSJ: 38-39)

'Laki-laki harus bekerja, apa yang didapat diberikan kepada istrinya. Yang perempuan melaksanakan dan menjaga kebutuhan sehari-hari, dengan uang yang dihasilkan oleh suami tadi. Nantinya perempuan bisa mereka-reka membantu kebutuhan sementara untuk meringankan laki-laki. Tidak janji bisa membagi apa yang diterima itu sudah bisa dikatakan cukup, atau itu karena laki-laki berat dalam mencari makan. Jadi yang menata membersihkan dan baiknya dalam rumah adalah perempuan, apa yang diperlukan, dan apa kekurangannya semua perempuan pasti mengetahui.'

Dari kutipan menjelaskan bahwa tugas dari seorang isitri adalah bisa menjaga dan mengelola keuangan dalam keluarga. Kebutuhan keluarga agar tercukupi bila seorang istri berhasil dalam mengatur keuangan atau ekonomi rumah tangga. Selain itu, Istri juga berkewajiban untuk menjaga kebersihan rumah.

4) Istri menyiapkan makanan

Dalam naskah tersebut dijelaskan bahwa tugas istri adalah membantu suami ketika dalam kesusahan dan membantu menyiapkan makanan. juga dapat dilihat dalam kutipan berikut.Hal tersebut tampak pada kutipan:

"Ing sadina-dina kang wadon iya mung tutulung kasusahaning wong lanang. Lan ambudidaya anane kang dipangan. Ana kang melu menyang 
sawah. Ana kang ameku kuluban, banjur olah-olah. Salawase wong wadon mau suwita wong lanang."

(LSJ: 13)

'Setiap hari si perempuan hanya membantu kesusahan si laki-laki. Dan mempersiapkan sesuatu untuk dimakan. Ada yang ikut ke sawah. Ada yang mencari sayuran, kemudian memasak. Selamanya perempuan tadi mengabdi kepada laki-laki.'

Dalam kutipan menjelaskan bagaimana peran seorang istri dalam rumah tangga, istri berkewajiban membantu kesulitan yang dihadapi oleh suami. Setelah menjadi sebuah keluarga, kesulitan yang dihadapi suami menjadi kesulitan istri. Sebagai istri yang mengabdi kepada suami, ia harus membantu dengan melaksanakan pekerjaan rumah dan mereka-reka kebutuhan rumah tangga. Kebutuhan dalam rumah tangga yaitu menyiapkan semua kenutuhan suami, salah satunya yaitu menyiapkan makanan.

5) Suami memenuhi kebutuhan Istri

Kewajiban seorang suami setelah menikah adalah mencukupi semua kebutuhan dalam berumah tangga baik sandang maupun pangan, berikut kutipannya:

"Wong wadon iku dadi wajibing wong lanang, mulane yen wis duwe bojo, saking ngadi-adine lan kaderenge, kawetu panjaluke marang sing lanang, arupa sandhangan, rerengganing panganggo, utawa prabotan paturon. Wusana kang lanang ora bisa nuruti, dadi wong wadon pingget atine. Anjalari wayaning leladen.." (LSJ: 31)

'Perempuan itu menjadi kewajiban laki-laki, maka jika sudah mempunyai suami, terlalu berlebihan dan terburu-buru, muncul permintaannya kepada si laki-laki, berupa sandang, kebutuhan pakaian, atau perabotan tidur. Jika si laki-laki tidak bisa memenuhi, si perempuan menjadi sakit hatinya. Menyebabkan berubah pelayanannya.'

Berdasarkan kutipan di atas terdapat keterangan bahwa setelah menikah, perempuan akan menjadi tanggung jawab laki-laki. Sehingga segala kebutuhan akan sandang pangannya menjadi tanggungan laki-laki. Istri akan meminta dicukupkan kebutuhan-kebutuhan tersebut oleh suami. Ketika suami tidak dapat memenuhinya, meyebabkan kekecewaan di hati istri. Jika sudah demikian, pelayanan istri terhadap suami akan berkurang.

6) Berperilaku sabar terhadap Istri

Perilaku sabar merupakan yang terpuji. Dalam sebuah hubungan keluarga, saling pengertian merupakan kunci dan kesabaran akan menghidarkan dari permasalahan. berikut kutipannya:

"Sabanjure manawa wong lanang talaten nununtun. Parentahe aja sarana sengol. Tembunge aja ana kang kasar, luwih maneh bisa amek-amek ati. Wong wadon amesthi miturut kanthi seneng, malah bisa wuwuh tresnane marang sing lanang. Wusanane tansah anjaga amrih senenging bojone, dadi gelem mikir lan niru kang wis diwulangake supaya bungahna. Lawaslawas pituruting guru laki kacakup kabeh, saiki pangarep-arepe sing lanang wis kasembadan. Wong wadon ora kanthi diparentah." (LSJ: 50) 
'Selanjutnya jika suami rajin menuntun. Perintahnya jangan dengan marah. Perkataannya jangan ada yang kasar, terlebih lagi bisa mengambil hati. Si perempuan pasti akan menurut dengan senang, malah bisa tumbuh rasa cintanya kepada suami. Akhirnya akan menjaga agar senang suaminya, jadi mau berfikir dan meniru yang sudah diajarkan untuk menyenangkan. Lamalama perkataan suami dapat diterima semuanya, sekarang keinginan suami sudah terpenuhi. Si perempuan tidak diperintah.'

Kutipan di atas terdapat penjelasan jika seorang suami harus bisa membimbing istri agar menjadi lebih baik. Perkataan suami hendaknya menggunakan kata-kata yang halus, bukan dengan kata-kata yang menyakitkan hati. Jika seorang suami dapat meluluhkan hati istrinya, secara istri akan menuruti semua perintah suami dengan rasa senang. Semua yang dipelajari dari suaminya akan dilaksanakan. Jika sudah demikian, lama-lama tanpa diperintah oleh suami, istri akan memenuhi kewajibannya dengan baik

7) Peran orang tua dalam pendidikan anak

Orang tua hendaknya memperhatikan dan memberi pendidikan pada anak sejak usia dini. Seperti dalam kutipan berikut.

"Bocah kang wis mudhak gedhe iku ora wiwit diwenehi piwulang, nanging dilemparake sagelem-geleme. Bapa biyunge lunga, anake dolan saparanparan. Yen ngelih banjur mulih anjaluk mangan. Yen wis wareg lunga dolan maneh."

(LSJ: 15)

'Anak yang sudah mulai besar tidak pernah diberi pendidikan, tetapi dibiarkan saja. Ayah dan ibunya pergi, si anak pergi bermain semaunya. Jika lapar akan pulang makan. Jika sudah kenyang kembali pergi untuk bermain lagi.'

Berdasarkan kutipan di atas, anak yang sudah mulai besar tidak kemudian diberi pendidikan oleh orang tuanya. Ayah dan ibunya pergi dan membiarkan anak pergi begitu saja. Ini menandakan jika kedua orang tuanya kurang perhatian terhadap pendidikan anak. Mereka tidak menyadari akan manfaat atau pentingnya pendidikan bagi anak untuk masa depan. Seperti dalam kutipan di bawah ini.

"Saya lawas bocah mau saya mundhak gedhe. Mundhak kukuwatane. Pitulungane menyang wong tuwane iya sangsaya wuwuh. Dadi wong tuwane kapihenaken oleh rewang anake. Ora pisan duwe pikir anake arep diajarake, lan diwulang kawruh rupa-rupa. Kang pamburine bakal maedhahi ing uripe." (LSJ: 16)

'Semakin lama si anak bertambah besar. Bertambah kekuatannya. Dalam membantu orang tuanya juga semakin bertambah. Jadi orang tuanya merasa lebih enak mendapat bantuan dari anaknya. Tidak berfikir sekalipun agar anaknya diberi pendidikan, dan diberi pengetahuan. Yang pada saatnya nanti akan bermanfaat bagi hidupnya.'

Kutipan di atas menunjukkan bahwa perhatian orang tua hanya terpusat pada kekuatan anak untuk membantu orang tuanya. Orang tua merasa diringankan pekerjaannya dengan bantuan dari anak. Padahal anak mempunyai masa depan yang harus diperhatikan. Orang tua seharusnya mengupayakan yang terbaik untuk kehidupan anaknya kelak. Jika tidak demikian, akan timbul penyesalan di 
kemudian hari. Agar tidak terjadi penyesalan, hendaknya orang tua berusaha memperbaiki tingkat pendidikan anak.

"Wong wadon kang wis kabanjur tuwa, kapriye maneh, iya kudu dinarima. Apa kang pelu didandani, ora liya anake wadon iku kang durung kedaluwarsa, prayoga padaha diajokake, supaya padha weruh marang pangajaran utama, ing tembe sawatara bisa ngirib-iribi sampurnaning wadon." (LSJ: 74)

"Perempuan yang sudah terlanjur tua, bagaimana lagi, iya harus menerima. Apa yang perlu diperbaiki, tidak lain anak perempuannya yang belum terlanjur, lebih baik diperbaiki, agar mereka tahu mengenai pendidikan utama, agar nanti bisa menambah kesempurnaan perempuan.'

Pendidikan untuk anak perempuan yang sudah berumur dan belum mengenal pendidikan, tidak salah jika anak tersebut memperbaiki untuk mempersiakan untuk masa depan anak. Dari kutipan di atas, sudah semestinya orang tua memperhatikan pendidikan anak, hal tersebut dipersiapkan untuk masa depan anak.

8) Istri harus mampu menyimpan rahasia keluarga

Pada serat Layang Sri Juwita juga mendeskripsikan perilaku seorang istri pada umumnya, yaitu kurang hati-hati menyimpan rahasia keluarga. Hal tersebut tampak pada kutipan berikut:

"Wong wadon manawa pinuju rerasan kena kapasthekake mung ngrembug pangan. Banjur ngrasani kang lanang, wong kang wis duwe mantu iya ngrasani mantun lan besane, utawa maneh sok ngomongake pagaweyane dhewe ing sadina-dina, wusanane dalah wadine diomongake kabeh."(LSJ: 26)

'Perempuan jika membicarakan sesuatu bisa dipastikan membicarakan makanan. Kemudian menggunjing si laki-laki, orang yang sudah mempunyai menantu maka akan menggunjing menantu dan besannya, atau lagi membicarakan pekerjaan sendiri setiap hari, akhirnya apa yang menjadi rahasianya dibicarakan semua.'

Berdasarkan kutipan tersebut dapat dilihat bahwa apabila seorang perempuan sudah berkumpul dan membicarakan sesuatu, mereka tidak bisa membatasi pembicaraannya. Berawal dari pembicaraan yang sepele, kemudian akan berkembang membicarakan hal-hal yang menjadi rahasianya sendiri, seperti membicarakan menantu dan besannya. Selain kutipan di atas, kutipan lain yang menandakan sifat perempuan yang tidak bisa menyimpan rahasia juga terdapat dalam kutipan berikut.

"Meh saben wong wadon ora bisa nyimpen wewadi, angger krungu rerasan, ala abecika iya bakal ditularake, terkadang kang dirungu mau enggone ngomongomongake diundhaki utawa disuda, nganti beda banget karo kanyatane, wusana kang ora seneng ngarani wong mau dobol lambene utawa gatel cangkeme." (LSJ: 41)

'Hampir semua perempuan tidak bisa menyimpan rahasia, jika mendengar gunjingan, buruk ataupun baik akan ditularkan. Terkadang yang didengar tadi ketika mengatakannya ditambah atau dikurangi, sampai beda sekali dengan kenyataannya, akhirnya yang tidak suka mengatakan orang tadi rusak mulutnya atau gatal mulutnya.' 
Berdasarkan kutipan tersebut, diterangkan bahwa perempuan memang tidak bisa menyimpan rahasia. Meskipun apa yang mereka ketahui baik atau buruk mereka akan menyampaikannya kepada orang lain. Terkadang perempuan juga suka menambah atau mengurangi informasi yang mereka dapatkan. Sehingga berita yang ia sebarkan sudah tidak lagi sesuai dengan yang kenyataan yang sebenarnya. Nilai pendidikan yang bisa diambil dari kutipan tersebut yaitu, seorang istri hendaknya harus mampu menyimpan rahasia keluarga.

\section{PENUTUP}

Serat Layang Sri Juwita merupakan serat yang memuat tentang ajaran berumah tangga. karya tersebut berisi mengatur atau mengajar kepada pembaca untuk bisa dijadikan bahan pengajaran untuk mencapai keluhuran hidup atau pelajaran hidup supaya selamat. Keluarga adalah pilar utama pendidikan bagi anak, karena keluarga merupakan tempat pendidikan dan sosialisasi pertama bagi anak. Pendidikan nilai budi pekerti sangat penting untuk diimplementasikan dalam kehidupan rumah tangga/keluarga. Dimulai dari pemilihan pasangan hidup, menjalani kehidupan berkeluarga, hingga mendidik dan membimbing hingga dewasa, sampai dengan berkeluarga.

Upaya-upaya nyata dalam proses pembinaan moral dan pendidikan dalam Serat Layang Sri Juwita dapat dilakukan oleh para pendidik (guru) atau tokoh masyarakat. Para pengajar dapat mengajarkan dengan memberikan kajian terhadap nilai yang ada dalam teks tersebut. Hal itu dimungkinkan masih relevan mengingat ajaran nilai-nilai moral, pendidikan, dan keluarga sangat dibutuhkan dalam proses pembentukan budi pekerti.

\section{Daftar Pustaka}

Akhmad Sudrajat. 2008. Teori Nilai dalam http://wordpress.com /2008/02/09/teori nilai. diunduh 29 Maret 2015.

Asia Padmopuspita. 1990. "Citra Wanita dalam Sastra" Dalam Cakrawala Pendidikan. Yogyakarta: Lembaga Pengabdian Masyarakat.Atar Semi. 1994. Anatomi Sastra. Padang: Angkasa Raya.

Burhan Nurgiyantoro. 2005. Teori Pengkajian Fiksi. Yogyakarta: Gajah Mada University Press.

Edi Sedyawati, dkk.2001. Sastra Jawa Suatu Tinjauan Umum. Jakarta. Balai Pustaka.

Hartoto.2009.Tujuan Pendidikan (fatamorgana.wordpress.com/2009/04/11/Tujuan Pendidikan) diakses 28 Maret 2015.

Koentjaraningrat. 1985. Metode-metode Penelitian Masyarakat. Jakarta: Gramedia

Linda, N.Eyre, Richard. 1995. Teaching Your Children Values. New York: Simon sand Chuster.

Mardiatmaja, B. S. 1986. Tujuan Dunia Pendidikan. Yogyakarta: Kanisius.

Nani Tuloli. 1999. Peranan Sastra dalam Masyarakat Modern. Jakarta: Pusat Pembinaan dan Pengembangan Bahasa. 